\title{
New Perspective in Development of Local Self-Government
}

\author{
Mirko Klaric \\ University of Split, Split, Republic of Croatia
}

\begin{abstract}
Croatian local government is organized in a two-tier system with a polytypic structure. On the first level are cities and municipalities with municipality and city mayors. On the second level are counties with some county prefects. The first level is charged for typical communal tasks, such as waste management, water supplies management, maintenance and social housing, urban planning, etc. On the second level are counties, which are charged for the coordination of urban planning of local units from the first level, and support for the local units from the first level in organization and managing of the local tasks and duties relating for everyday life of people in local communities. But responsibilities, tasks, and duties are not so clear defined, so it exists overlap between these two levels of local self-government. The second question, which is related on processes of decentralization, is a question of role of sub-municipal government in local government of Croatia. This text will be analyzing possibilities of reform of these two levels of local government, and suggesting possible solutions for settlement of those problems.
\end{abstract}

Keywords: local self-government, counties, sub-municipal government units, decentralization

\section{Introduction}

Croatia is a country geographically located in south-east part of Europe. As a country, Croatia is on the Mediterranean, central European and oriental politically and cultural influence. Predominantly, it is a county which shares history of central European countries and presents some kind of border state between central and eastern and south-eastern Europe. Croatia is also member state of European Union.

Croatia is a small country with the territory which connects Mediterranean, Danube, and Alps. It is unitary state with a more than 90 percent of declared Roman Catholic and Croats. Local government system of Croatia is organized in a two-tier model with a polytypic structure at the first level.

On the first level are cities and municipalities with municipality or city mayors. On the second level are counties with county prefects. The first level is local political units, which are designed for some typical communal problems, such as waste management, water supplies management, maintenance and management of the local roads, organization of local transport system, social housing, and urban planning. On the second level are counties, which are charged for coordination and harmonization of urban planning for a bigger area and technical support for managing of local tasks and duties on the first level. But the tasks, obligations, and responsibilities are not so clearly defined, and it can be predicted overlap between these two levels of self-government units (Ivanišević, 2008, pp. 8-9). Many of Croatian scientists and practitioners mean that Croatia

Mirko Klarić, Dr., Sc., full professor, Department for Administrative Sciences, Faculty of Law, University of Split, Split, Republic of Croatia. 
needs a reform of local self-government system (Koprić, 2010; Bakota \& Grbanović, 2011; Blažević, 2018; Đulabić, 2005). There are two field of possible reform. The first is role, organization, and responsibility of counties in managing of local public tasks. The second field of reform is neighborhoods, which have relatively undefined position in Croatian local government system. ${ }^{1}$

Counties are not completely defined as local government units and need reform which include fiscal, administrative, and political decentralization (Hodžić \& Muharemović, 2019). Every aspect of decentralization is complex, and asks preparedness for many challenges in this process (Saito, 2008). The first of them is creating of stronger institutional capacity and capacity building (Koprić, 2003). The second is preparedness of fiscal capacity, especially public incomes enough to finance local public tasks and obligations. The third is political will for institutional changes to create reinventing local government. ${ }^{2}$ Today, counties have strongly addiction on central government, because it is impossible to manage any serious structural or economic project without support of central government. The role of central government is crucial in preparedness and executing of many local public policies, which are related with the county level. That is the reason why political elite on county level strongly depends on support of central government. Counties in Croatia can be compared with other local government units in other European countries. For example, they are comparable with the similar type of units in France (departmans), Italy (regions), Poland (powiats), Czechia (districts), Slovakia (okresy), and Nederland (provinces). Someone is bigger than Croatian counties (in Nederland, Italy, and France); in other states are more similar (for example, in Poland, Czechia, and Slovakia).

Neighborhoods are type of sub-local units, which exist in Croatian statute law, but without any officially public authority. They exist in many of Croatian cities and municipalities, but they have only advisory function. They can only propose certain measures important for everyday life of local community. Their role in everyday functioning of local self-government is totally unimportant. They do not have any autonomic public authorities and responsibilities. Because of that, they cannot provide some local public services, which are of sub-local interest. Even when they can initiate this type of services from local-government units, they are depending of the good will of local mayors. This is the reason why many of Croatian scientists and practitioners think that the role of the municipal sub-government must be changed. They think that the role of the neighborhoods must be more visible, especially in some future process of decentralization of local government units. In this paper it will be analyzed role of local government units in Croatian local government system and possibilities of future and possibilities of future development of Croatian local government system.

\section{Methodology}

In this paper, as a methodology, it will be used comparative analysis of different types of local self-government, compared with local self-government in Croatia. Method of comparative analyze can help to

\footnotetext{
${ }^{1}$ Local self-government units were existed as a form of territorial organization long time before establishing of central political and administrative system. In the past, the first local community created local political and administrative units, and central political authority appeared with establishing of modern state (Pusić, 2002, pp. 70-72).

${ }^{2}$ One of the main problems in Croatian local self-government system is a question of transparency and openness. One research from 2011 shows that $70 \%$ local and regional units were assessed as non-transparent, while only $7 \%$ is scored as a remarkably transparent. The highest level of transparency was demonstrated by cities and the lowest level by municipalities. County was mostly transparent (Musa, Bebić, \& Đurman, 2015).
} 
detect some key points who have deep impact for organization and functioning of local self-government. Main question is how local self-government in Croatia functions, comparing with the other types of local self-government which can exist in other countries, because it can exist ideal type of local self-government: first highly centralized, and second highly decentralized. The second question is analyzing of that type of organization in Croatia, true relations between executive and representative bodies. The third question is analyzing complete system of local self-government and relations between counties on the second level, counties and towns on the first level and sub-municipal government in city or municipality units with their relation with central government administration (Manojlović, Vukojčić, \& Koprić, 2019). The fourth question is process of development of Croatian system of local self-government and possible direction of that development in the future (Koprić, 2015).

After analytic approach, it is necessary to apply method of synthesis, which can help to provide expectations for the future development of local self-government in Croatia, and includes local self-government units on the first and second level, and also sub-municipal units. That can assure some remarks relating for development processes of local self-government system in Croatia, and their relation with the central government administration. Past development of local self-government in Croatia, with present dynamic in creating of political and social system, can be helping in analyze of future processes in Croatian local self-government system. That can be useful for prevision of future development of Croatian self-government system, regarding to its relation with central government administration and sub-municipal government.

\section{Main Objection Relating on Functioning of Local Self-Government System}

Local self-government system includes stronger or lower autonomy of local self-government, which depends on organization system and relations between central government administration and local government units. ${ }^{3}$ In that sense, it is quaintly irrelevant the number of local units, or organization of local government in a one-tier or two-tier system. It is more important political, organizational, and fiscal capacity of local government units. $^{4}$ This capacity is crucial for efficient and visible local government. ${ }^{5}$

But, for establishing of modern local self-government system, it must be constructed some purposes of local government, their role in political and administrative system, and conceptions of organization of local public units, which is crucial for functioning of political and administrative system in some country. ${ }^{6}$ It may be some questions in matter, such as the public tasks and public authorities of local self-government units, and relations

\footnotetext{
${ }^{3}$ Some of the countries can have local government system with strong influence of central government. France had this approach, which large number of municipality units. Now, it exists two-tier system with communal units at the first level, and on the second level departments and metropoles. Metropoles are units which are established for territory of more communal units which are located in metropolitan area. Metropoles manage some public services relevant for metropolitan territory (Breuillard, 2015).

${ }^{4}$ In that sense, bringing services closer to the citizens is one of the primary goals of local self-government, but different social groups in local community have different needs, and local government must be responsive to fulfill those needs (Maksimovska \& Stojkov, 2016).

5 For example, when existing need for managing some services on local level, such as waste management, or water supply, local government units must have serious institutional capacity (Sarvan, 2016).

${ }^{6}$ In that sense, decentralization can be assumed to benefit subnational government by increasing its autonomy from central government. Some research shows that some decentralizations policies may result in greater subnational autonomy from national government, and some decentralizations policies may increase a subnational unit's dependence on national government (Vezbergaite, 2016).
} 
with the central state authorities. ${ }^{7}$ The main question is which public tasks are managing by local government units on the first level, the second question is which public tasks are managing by local government units on second level, as a local public tasks, and the third question is the role of sub-municipal government, if exists, on managing of local public tasks. ${ }^{8}$ Every level of administration has their own responsibilities, and regards on political system and delivery of public authorities. ${ }^{9}$ Some of the countries decided to have centralized public administration; other decided to develop of highly decentralized public administration, with strongly influence of local self-government in public management (Rosenbaum, 2003). In case of highly decentralization, local government units have important role in managing of public tasks which are important for daily life of citizens. In other situation, local government units participate only in those tasks which are important for local communal needs of local community, such as communal services. The main question in that case is whether local communal units have or not serious institutional and organizational capacity to support managing of tasks who have local relevance, because someone of local public tasks is complex for providing, such as water supply, waste management, etc. ${ }^{10}$ In that sense, we can impute relations between some of the levels of government. If it is promoted model of public governance with strong central state, it usually existed weak local government units, with small institutional capacity. ${ }^{11}$ In that case, we do not need sub-municipal government, because those local units can manage all local public tasks for local community. Weak local government units can provide all local public services, which are relevant for some small local community. In that case, role of the sub-municipal government is undefined, and need for existing of that type of units is not so present. If they exist, usually that is only as an advisory body, with very low influence on local political decisions relating on managing of local public tasks. Advisory role of this type of body is usually oriented on daily needs of some parts of local communities, and canalizing of those needs to local units.

In other situation, when existing local public units with strong institutional capacity, in highly decentralized countries, local self-government has higher influence on managing of public tasks in local community. ${ }^{12}$ In some countries, local public units deliver all public services to community at local level, and the difference is only in the question on which level of government is in charged to decide in various political decisions. This situation of highly decentralized local self-government system can open a possibility for strengthening of sub-municipal

\footnotetext{
${ }^{7}$ In some Europian states, transition processes and European integrations dictate regulation of relations between local and central public authorities. For example, Poland cities, as an actor, are tangled in numerous regional, national, and European networks, which are overlapping in many aspects and contribute to the complexity of the present system (Lackowska, 2014).

${ }^{8}$ For example, Slovenia is example of the one of the centralized countries of Europe, and its centralization is "strengthened further by the large number of inefficient municipalities". This situation is one of the most important challenges in future development of local self-government system in Slovenia (Pevcin \& Rakar, 2015).

9 It cannot be ignored influence of European institution on local government. For example, in Poland, we discuss how EU integration impacts on policies formulated and implemented by Polish local government (Swianiewicz, 2014).

${ }^{10}$ This is actual question even in old democracy institutions, such as local government in England, because of the tendency of transformation from the local government to the local governance, which means more transparency and citizen's engagement in the work of local community (Copus, 2015).

${ }^{11}$ For example, Slovenia has small local government units, but their authorities are like the authorities of largest ones. One of the main problems of this small municipality is a small institutional capacity for managing of local public tasks, which shows research provides by M. Haček and I. Bačlija (2014).

${ }_{12}$ In land, like China, it is quietly difficult to speak about central and local government administration and their relations, because in China, it dominates opinion that Chinese local government strongly participates in provision of public services. Even more, in China, research community seems that many of Chinese public policies have predominant local character (Dong, Qin, \& Christensen, 2015).
} 
government, because in that case, sub-municipal government can increase more significant role in the life of the local community. In that case, sub-municipal government can assure delivery of some local public services, which are important for daily life of some small part of local community, with a specific need and aim which should be satisfied. Local self-government units can manage some larger projects, such as water supply, waste management, building of local infrastructure, strongly support to economic activities of local companies, etc. Sub-municipal government can support some local activities, which induce quality of life in local community.

In situation where we have strong sub-municipal government units, it is possible to detect specific three main aspects of sub-municipal government: advisory role in delivery of local public services, organizational role in managing of daily local tasks, and supporting role in developing of public projects, which are from local relevance. Advisory role is important for coordination between local-government level and local communities. Local communities have specific local public needs, and they need support of sub-municipal government to canalize these expectations from local self-government units. Sub-municipal government mediates between local self-government units and local communities to promote of fulfilling of local public needs and managing of local public tasks. The second aspect is organizational skills to for autonomic provision and delivery of some simple local public services. Those abilities help sub-municipal government to organize more inclusive approach to the local communities and their specific local public needs. Some of local public tasks can be object of these activities: provision of local public security, cooperation with local police force in promoting of public security, organization of local social activities, and organization of some simple communal services, such as arrangement and maintenance of local parks and green areas for recreation, etc. The third aspect is assuring organizational and logistic support for managing of some public project and programs, who may have local importance for daily living of citizens in local communities. In local communities, they need direct approach to sub-municipal government organization, what is easier because of the type of organization, which is directly openness to the local community and it needs. Because of its direct approach in communication, sub-municipal organization can be effective in supporting of various activities and initiatives of local communities.

This type of organization of local self-government system, which includes organizational and institutional decentralization, main focuses places on local structures, which they have large capacity for managing of public tasks, according to the principle of subsidiary, as a one of the main principles in organization of local self-government. This type of organization includes territorial bigger local units, and usually introduces organization of self-government on regional level. The main goal of this model of organization is higher participation of citizens in local public tasks and better control of functioning of local self-government, cause of better visibility of activity of local government units. ${ }^{13}$

This model of organization has strong institutional capacity, and provides various public services to the local self-government. Many of complex public services are also provided locally by these organizational units, and they have personal and financial strength to deal with managing of those activities, which assure delivery of the services thru the local community. In that sense, we can speak about applying of principle of subsidiary in local

\footnotetext{
${ }^{13}$ Democratization and decentralization are most important processes in local government reforms in Central and Eastern Europe, but the possibility for change is different. It depends on many aspects, such as political situation in the country, preparedness for change and belonging to a certain international political association, such as European Union. The best example is comparison between the reforms of local self-government system in Russia, Poland, and Romania (Lazin, 2014).
} 
self-government system, which considers that local government units have advantage instead of central government units. This advantage exists because local government units are considered with their territorial organization much closer to the ordinary citizens in local community, than government administration on central level. In that sense, advantage in delivery of local public services is always on side of local self-government units, especially in situation when those types of units have institutional, organizational, and fiscal capacity to manage local public tasks. This situation introduces possibility of local management by many of various public tasks, which can assure influence of local community in delivery of public services, according to the local public needs.

When space for organization of highly decentralized local government exists, it is possible to create space for functioning of sub-municipal government. ${ }^{14}$ This type of local units has two main roles. The first one is, in fact, that sub-municipal units have possibility to deliver some simple local communal services, which are of daily importance for local community. The second role of this type of self-government is advisory one, where sub-municipal units are detecting problems in daily life of local community, and give suggestions for their efficiently settlement. In that sense, sub-municipal government can encourage individuals in the local community to engage in community life.

It can be detected a few moments in managing of local public services in the case of strongly decentralized local self-government system. At first, local government units have strongly institutional and organizational capacity. Second, usually their fiscal capacity is also stronger, with potential to assure managing of more complex public services. Third, strong institutional, organizational, and fiscal capacity of local government units can provide possibility for delivery and management of many of public services. Fourth, citizens in the local community can have more influence on management and delivery of local public services. Fifth, this occasion can strongly influence on democratic processes in local community and strengthen democratic processes in the local self-government units and wider in political system. Sixth, openness of local government to local community and higher control from the citizens leads to transparency of public administration. That helps in assuring of higher standards in managing of local public tasks. ${ }^{15}$

Other model includes weak local self-government on the one side and strong central state administration with large public authorities on the other side. This is completely different approach in regulating of public administration in country. In this type of local self-government, local units are usually oriented on delivery of some simple local public services, such as housing, local communal services, and urban planning. Some of the public tasks, which are more complex for managing, such as education, health services, waste management, and water supply, usually operate by central government administration or central government units which are organized locally, to provide services to the local community. In that case, it exists subordination between central and local administrative bodies, and central government administration can route activity in managing of public tasks and delivery of public services to the local community. This approach includes strongly influence of central

\footnotetext{
${ }^{14}$ Sub-municipal units usually established in large self-government units. For example, in Germany, sub-municipal units are introduced in cities over 100,000 inhabitants (Kersting \& Kuhlmann, 2018).

${ }^{15}$ We can also detect changes in developing of local government systems of certain states, which became from centralized country with weak local self-government units' state with strong local government units, such as Poland. In Poland, regional self-government units became actors with increasingly important role in implementation of EU cohesion policies. Poland, which at first has weak regional self-government, is today defined as a "regionalized unitary state" (Swianiewicz, 2014).
} 
government administration to the local public affairs. In that case, sub-municipal government does not have some important role in functioning of local community. Sub-municipal government in that situation can be organized at sub-municipal level, but not necessarily. ${ }^{16}$ If those types of organization exist, sub-municipal units have advisory role in managing of local public policies, and this type of units helps to local self-government units in articulation of public needs of local community, and helps in preparedness to fulfill local public needs. Sub-municipal government can prepare possibilities at local community level to assure better local public services, which are important for daily life of local public community. The main problem which is in relating with position of municipal sub-government is secondary role in functioning of local public tasks. Secondary role depends on needs of public community. Public community needs some necessary public services, and sub-municipal government has advisory role. This role has limited influence, because local self-government units have origin authorities, and they can decide in cases where are independent.

\section{Local Self-Government in Croatia}

Croatian local self-government system is created from the units in the three possible levels: On the first level are sub-municipal units (parishes), on the second level are municipal units (towns and municipalities), and on the third level are county units (counties). ${ }^{17}$

For the county units in Croatia, sometimes people use term regional units, but in fact, regional units in administrative theory usually have more serious public authorities than the counties in Croatian local self-government. Croatia has various forms of local government units, but their public jurisdictions and possibilities for managing of local public tasks are limited. In that sense, Croatia has branchy forms of local government units, but their public authorities and public jurisdiction on managing of local public tasks are limited. Some of these tasks are familiar with the tasks in other local self-government units.

But, if discussing about highly decentralized country, Croatia is a far away from that. Croatian local self-government units have no public tasks which can be recognized in highly decentralized country. In highly decentralized country, we can see that public authorities are in the hand of the local self-government units, and those units have strong influence on everyday life of ordinary people, who live in those units of local self-government.

In Croatia, public tasks and responsibilities are limited on urban planning and communal services. Autonomy in other public service activities is rare, and many of public tasks, obligations, and authorities are in fact in hands of central government authorities. There are many discussions about possibility and need for decentralization of powers on local self-government units, but these questions are still open. On the one hand, there is no political will for changes on central political level; on the other hand, there is an absence of political will in the local self-government level, because process of larger decentralization means reorganization of local self-government system. For many of local self-government units, it means possibility of their nullification and creation of some larger local self-government units. Larger type of units can have increasing institutional

\footnotetext{
16 This model is very close to the English forms of sub-municipal government. In England exists various types of sub-municipal government, more or less formal or informal, such as neighborhood bodies, government inspired schemes, service oversight bodies and parish and town councils (Copus, 2018).

${ }^{17}$ In Croatian political system, the first level of self-government, sub-municipal government has only facultative form, and it is not regulating with Constitution. This type of self-government is regulating with the statute law (Koprić, 2018a).
} 
capacity, because of their size. But this means organizational changes, and local political elite' gives resistance to these achievements and callings to the local government reform. In this moment, it can be expecting some reforms which are opening through the process of decentralization, and includes strengthening of process of decentralization.

At the first level of local self-government system in Croatia, municipalities and towns are primarily charge for local urban planning and various local communal services, which they manage them singly or together with another one or more local self-government units. The second level is counties, which are primarily in charge for public tasks decentralized from central state administration. Those public services are decentralized in a way that they are responsibility of counties, but they are still controlled from central government. Also, central government gives money for managing of these duties. The second role of the counties is possibility of revision of decision in the local government units at the first level. That role is important for municipality or city units, especially in the field of communal services and taxes, and also in context of validation of decision of municipality of city council, relating with the question, such as urban planning. The main role of the counties is mediation between central government and larger local community, and support of daily functioning of local self-government units on the first level.

Sub-municipal government is a third, informal level of government. It is informal level, because in Croatia, it excludes formal public jurisdiction. Their role can be significant, but their influence depending on occasions and circumstances in every local self-government unit. If someone local self-government unit considers that position of sub-municipal government must be stronger and visible, in that case, sub-municipal units have more influential role in managing of local public tasks, which are relating of daily life in some small sub-local community. In the other situations, the role of sub-municipal government units in Croatian local self-government system is a minimal, and they have only advisory role, which concerns discussion about some questions which are relating with daily life of ordinary people in some local community. Those questions are usually connected with some questions as a quality of some delivered local communal services, ordinary communal problems, main questions related with communal orders, typically questions important for delivery of local communal services, quality of communal tasks from local communal utilities and the other questions relating for everyday life of a small local communities. In that sense, sub-municipal government units can have increasable role in managing of local public tasks in local self-government system in Croatia.

\section{Historical and Institutional Development of Local Self-Government in Croatia}

Croatia has a large number of local municipalities and cities ${ }^{18}$ at the first level, with small surface and small number of inhabitants. On the second level are established 20 counties and capital city Zagreb with status as a county $^{19}$. This type of local self-government system is introduced by law on local self-government and

\footnotetext{
18 In Croatia exist 428 municipalities and 127 cities. https:/uprava.gov.hr/o-ministarstvu/ustrojstvo/uprava-za-politicki-sustav-i-organizaciju-uprave/lokalna-i-podrucna-regionalna-sa mouprava/popis-zupanija-gradova-i-opcina/846.

19 Capital cities have usually special positions in system of local self-government. That situation is in Croatia with Zagreb, but also in Great Britain with London. In 1999 was introduced Greater London Authority Act, which established directly elected mayor for London and Greater London Assembly of 25 elected members, which together constitute the Greater London Authority (Copus, 2014).
} 
administration ${ }^{20}$ in 1992 year. ${ }^{21}$ By this model was introduced hybrid type of organization, which in the second level includes counties as some local self-government units, but also administrative units. Representative bodies of local self-government units were municipality or city councils and county assemblies. Other parts of direct democracies in Croatian local self-government system ${ }^{22}$ are referendums and local citizens' initiatives. ${ }^{23}$ Executive bodies were municipality, city, or county boards. Mayors and prefects were members of a municipality, city or county boards, and they have equal rights as the other members of a board. Members of municipality, city and county boards were elected by municipality or city councils, or county assemblies. They created collectively all decisions relevant for functioning of local self-government units and shared responsibility for those decisions. Main problems were high level of centralization, fragmentation of local self-government units and complicated relations between local self-government and local administration. Sub-municipal government is predicted, but it has only advisory role. Also, sub-municipal government units cannot be in legal sense legal entity, which can be additional problem for efficient organization of sub-municipal government. On the other side, advisory role of sub-municipal government does not make it visible enough. Possibility of influence sub-municipal government in this model of local self-government system is very limited to daily life of local community.

In Croatian, local self-government system was implemented three main reforms. The first was reform in 2000 and 2001 year. In 2000 year was reformed institutional position of local self-government in Croatian Constitution. ${ }^{24}$ Then in 2001 year were implemented ${ }^{25}$ various changes in organizational structure of local self-government system. ${ }^{26}$ Those changes have included new public authorities and tasks for local self-government units, but also division between local and central government public services and tasks (Đulabić \& Čepo, 2017). In that division many of public tasks, which are provided centrally, are became, at a first sight, local public services (Marčetić \& Lopižić, 2017). Their public authorities and obligations were arranging by new law on local and areal (regional) self-government. But the ways of financing of public tasks and local public services were centralized. ${ }^{27}$ Organization of sub-municipal government is changed, and new law predicted possibility in legal sense to organize sub-municipal government units as a legal entity, which gave possibility for better organizing of sub-municipal government in larger local self-government units. Their role is still advisory,

\footnotetext{
${ }^{20}$ Zakon o lokalnoj samoupravi i upravi, Narodne novine br. 90/92.

${ }^{21}$ So called Christmas Constitution from 1999 year has established new organization of local self government system In Croatia, with enumeration of public authorities of local self-government units. This method can cause some difficulties, such as technical complexity, problems in managing of some tasks which are primary in jurisdiction of central government administration, etc. (Koprić, 2014).

${ }^{22}$ Like in other European countries, in Croatia, there also exist possibilities for using some participatory instruments for strengthening of local democracy including of citizens in managing of local public tasks. There are more forms of direct democracy, such as direct election of mayors with direct recall procedure, youth councils and independent local political actors (Koprić \& Klarić, 2015).

${ }^{23}$ It is argued that these instruments "do not lead to binding decisions", because of the number of citizens who participate, which is relatively small, comparing with the elections (Kersting, 2015).

${ }_{24}$ Ustav Republike Hrvatske (Narodne novine broj 56/1990, 135/1997, 8/1998, 113/2000, 124/2000, 28/2001, 41/2001, 55/2001, 76/2010, 85/2010, 5/2014).

${ }_{25}$ Zakon o lokalnoj i područnoj (regionalnoj) samoupravi, Narodne novine br 33/2001.

${ }^{26}$ This reform was characterized with introduction of relatively large self-government jurisdiction and autonomy for local government units (Koprić, 2018b).

27 Those remarks are related with the financing of public health and educational system. Primary and secondary level of public health is managed by local political units, but financing of health Institutions is in hands of central government administration. Public education, wich cover elementary and high scholls are in hands of local self-government, according to the laws which are regulating this specific fields, but their financing is organized centrally.
} 
but large local self-government units have possibility to organize serious network of sub-municipal government units, and delegate them more tasks and services important for daily life in local community. Position of sub-municipal government is not ideal, but is better than before, because it is created legal basis for institutional building of sub-municipal government in some local self-government units.

The second institutional reform, which was important for organization of local self-government units in Croatia, was established by law enforcement in $2005{ }^{28}$ With these changes, new type of local units-large cities was introduced. Large cities became units equated with the county. This was attempting to decentralize some local public tasks from counties to larger cities in counties. There are two alternative criteria for status of large city: First, city must have at least 35,000 inhabitants; alternatively, city must be residence of county. By this definition, large cities are not only cities that have minimally 35,000 inhabitants, but also cities that have less than 35,000 inhabitants, but they are also residences of their counties.

Third important reform was in 2007, when is established new way of election of mayors, and abolished municipality, city and county boards. ${ }^{29}$ All executive authorities are assigned to the municipality and county mayors and county prefects, and they became only and exclusive executive bodies in local self-government. On the one hand, that has strengthened the position of municipality and city mayors and county prefects. On the other hand, that opened space for more responsibility in managing their public duties.

Last important change is created by law in 2017 year, where was changed relation between mayors and prefects as executive bodies on one side, and municipality and city councils and county assemblies on the other side. ${ }^{30}$ This relation has balanced by stipulation which regulates the adoption of the budget of local self-government units. The only authorized proponent of the budget is municipality or city mayor and county prefect, and they only can propose local budget to the representative bodies. If they do not want do propose local budget, the Government of Republic of Croatia will resolve them at the proposal of central public authority responsible for managing of public affairs. Municipality and city councils and county assembles need to accept the proposed budget of local self-government units. If they would not accept proposed budget, the Government of Republic of Croatia will dismiss the representative body in municipality, city, or county at the proposal of central public authority, responsible for managing of public affairs. ${ }^{31}$

Present local self-government system in Croatia has some characteristics, which can be analyzed in this paper. Croatian local self-government system has large number of local self-government units on the first level (428 municipalities and 127 cities) and second level (20 counties plus Zagreb, who has, as a capital city, status of county). ${ }^{32}$ The first level of local self-government is in charged for communal tasks and urban planning; the second level is in charged for urban planning of upper level, which coordinates urban planning of local self-government units. Other tasks of counties are elementary and secondary education, organization of public health service, managing of maritime goods, servicing of local public roads, etc. Many of those activities depend

\footnotetext{
${ }^{28}$ Zakon o izmjenama i dopunama zakona o lokalnoj i područnoj (regionalnoj) samoupravi, Narodne novine br. 129/2005.

${ }^{29}$ Zakon o izmjenama i dopunama zakona o lokalnoj i područnoj (regionalnoj) samoupravi, Narodne novine br. 109/2007.

30 Zakon o izmjenama i dopunama zakona o lokalnoj i područnoj (regionalnoj) samoupravi, Narodne novine br. 123/2017.

31 This change of law was from media and many public administration experts called Lex Sheriff, because it gives lot of political influence in hands of municipality and city mayors and county prefects. Many of them think that this amendment of law strengthening position of executive bodies contrary to representative bodies in local self-government units.

32 As a type of local self-government unit, counties have been implemented in Croatian territorial system in 1993 year. But their role, conception and significance are changed during the time (Koprić, Marčetić, Musa, Đulabić, \& Lalić Novak, 2014).
} 
on assistance and support of central government administration. Basically, only communal services and urban planning as activity of local self-government units are independent from the influence of the central government administration. Other activities need financial assistance or support of central government. That is the reason why central government administration can have highly influence on local self-government units, especially on counties. Sources of financing many of activities and tasks of local self-government are organized centrally, and central government has large impact on distribution of that money. Sub-municipal governance does not have large impact on local self-government system in Croatia. Influence of sub-municipal governance is very limited, because it does not have any originally public authorities, and has only advisory function. The role and position of sub-municipal government depends on local politics and local public policies. Importance of sub-municipal government is more express in larger self-government units, which have more inhabitants and large territory, then in smaller, because small units usually have directly communication with local community. Large local self-government units existing evidenced lack of communication between local community and local bodies, and sub-municipal government can improve this communication in solving of local public needs.

\section{Conclusion}

Croatian local self-government has three level of organization. One level is sub-municipal; other two are organized as a two-tier system. Sub-municipal level is regulated only by statute law, and with the statutes of municipality units. Other two levels were regulated in basic aspects with Croatian Constitution. Secondary, complete organization and relations in Croatian local government system is regulated by statute law. On the first level exists polytypic structure of municipal units, with a cities and municipalities, which have different tasks and public authorities, and that depends on their size. Large local units have institutional capacity for managing more local public services and tasks, and small municipalities are oriented to provide only basic public services. On the second level exist 20 counties and capital city Zagreb which has status of county. Counties in Croatia are not typical regional units. They are more local units in the second grade, and they represent type of units which manage more decentralized tasks for more local self-government units at the first level on their territory. This task is generally more or less financed from the central state budget, so many of these services depend on the central government administration support. Sub-municipal government does not have relevance in small municipalities, but exists in large local government units. It is especially relevant in the bigger cities, which are usually residence of the counties. Because of the size of units, it is naturally to have sub-municipal government, which can help in providing of local communal services important for daily life of local community.

Croatian local self-government system has a few open questions. Those questions are connected with the future development of Croatian self-government. The first question is related with the number of counties. Some of the practitioners and scientists think that is too many for a country, like Croatia. The second question is related with the number of municipality units and their efficiency in managing of public tasks. Some of practitioners and scientists think that this number must be reduced, or small local units just need different organization, with a different authorities and organizational structure. The third question is connected with position of sub-municipal government, especially in large local units. Present position of sub-municipal government in local self-government system is not entirely visible. Some of the local public units do not have sub-municipal government, some have organized sub-municipal government, but their role is only advisory. Sub-municipal 
government usually has some impact on managing of local public services to the local community only in the larger Croatian cities. This impact is connected with some tasks and duties which improve quality of life citizens in local community on daily basis.

For many public administrations' experts, current system of local self-government in Croatia is not efficient and needs change. But, real question is: which change and in which direction? Some experts think that Croatian local self-government must be regionalized with reduced number of local government units on the first level; others think that it needs to reform first level of local self-government and reduce number of cities and municipalities without touching a county level. There is also opinion that reform of local self-government deserves systematic approach and systematic changes, which include also sub-municipal government. In this moment, it can be expect more decentralization and transfer of some public services, some public jurisdiction and some public tasks from central government administration to counties and large Croatian cities. In the future, we can predict deprofessionalization of some public positions in small local government units. But some larger organizational changes of local self-government, which includes fiscal decentralization and redefinition of relations between central government administration and local self-government units, are very hard to expect. In that sense, only global economic crisis with strongly influence on European Union and Croatia can induce some large reforms of present Croatian administrative system, which include reform of local self-government as a part of public administration in Croatia.

\section{References}

Bakota, B., \& Grbanović, T. (2011). Reforma lokalne i regionalne samouprave s posebnim osvrtom na funkcije županije. Pravni Vjesnik, 27(2), 179-199.

Blažević, R. (2018). Problemi hrvatske lokalne samouprave i moguća rješenja. In I. Koprić (Ed.), Europeizacija hrvatske lokalne samouprave. Dva desetljeća primjene standarda Europske povelje o lokalnoj samoupravi (pp. 103-128). Zagreb: Institut za Javnu Upravu.

Breuillard, M. (2015). Local democracy in France: Improvements and shilly-shallying. Croatian and Comparative Public Administration, 15(2), 357-372.

Copus, C. (2014). London government: Problems, perspectives and power. Croatian and Comparative Public Administration, 14(3), 813-820.

Copus, C. (2015). Ideology or realism in government: A case of real local politik in English local government. Croatian and Comparative Public Administration, 15(2), 335-356.

Copus, C. (2018). Decentralization, democratization and delivery: English sub-municipal devolution. In N. Hlepas-Komninos, N. Kersting, S. Kuhlmann, P. Swianiewicz, and Teles, F. (Eds.), Sub-municipal governance in Europe: Decentralization beyond the municipal tier (pp. 69-91). London: Palgrave Macmillan.

Dong, L., Qin, C., \& Christensen, T. (2015). Local public services provision in China. Croatian and Comparative Public Administration, 15(3), 617-644.

Đulabić, V. (2005). Some developmental processes of local self-government regulation in the Republic of Croatia. Croatian and Comparative Public Administration, 5(1), 110-136.

Đulabić, V., \& Čepo, D. (2017). Regionalism and sub-regional representation: A guide to the county transformation in Croatia. Croatian and Comparative Public Administration, 17(4), 539-568.

Haček, M., \& Bačlija, I. (2014). Can small localities perform? Trends in administrative capacity in Slovenian municipalities, Croatian and Comparative Public Administration, 14(1), 85-194.

Hodžić, S., \& Muharemović, A. (2019). Fiscal decentralization and efficiency of regional government in Croatia: A data envelopment analysis. Lex Localis, Journal of Local Self-Government, 17(3), 453-470.

Ivanišević, S. (2008). Izvršne institucije u lokalnoj samoupravi. Zagreb: Institut za Javnu Upravu. 
Kersting, N. (2015). Local political participation in Europe: Elections and referendums. Croatian and Comparative Public Administration, 15(2), 319-334.

Kersting, N., \& Kuhlmann, S. (2018). Sub-municipal units in Germany: Municipal and metropolitan districts. In N. Hlepas-Komninos, N. Kersting, S. Kuhlmann, P. Swianiewicz, and Teles, F. (Eds.), Sub-municipal governance in Europe: Decentralization beyond the municipal tier (pp. 93-118). London: Palgrave Macmillan.

Klarić, M. (2015). Capacity of municipal sub-government for decentralization. Retrieved from http://iju.hr/IPSA/2015/files/05-03.pdf

Koprić, I. (2003). Local government development in Croatia: Problems and value mix. In H. Baldersheim, M. Ilner, and H. Wollmann (Eds.), Local democracy in post communist Europe (pp. 181-210). Wiesbaden: VS Verlag für Sozialwissenschaften-Springer.

Koprić, I. (2010). Suggestions for local and regional self-government reform in Croatia. Croatian and Comparative Public Administration, 10(4), 941-958.

Koprić, I. (2014). Problemi s decentralizacijom ovlasti u Hrvatskoj-Između ustavnih načela i stvarnosti. Hrvatska I Komparativna Javna Uprava, 14(1), 133-148.

Koprić, I. (2015). Zašto i kakva reforma lokalne samouprave u Hrvatskoj. Croatian and Comparative Public Administration, 15(4), 993-998.

Koprić, I. (Ed.). (2018a). Novela Zakona o lokalnoj i područnoj (regionalnoj) samoupravi iz 2017. In Europeizacija hrvatske lokalne samouprave (pp. 57-101). Zagreb: Institut za Javnu Upravu.

Koprić, I. (Ed.). (2018b). Suvremeni trendovi u razvoju lokalne samouprave i hrvatska lokalna i regionalna samouprava. In Europeizacija hrvatske lokalne samouprave (pp. 1-56). Zagreb: Institut za Javnu Upravu. .

Koprić, I., \& Klarić, M. (2015). New development in local democracy in Croatia. Croatian and Comparative Public Administration, 15(2), 389-414.

Koprić, I., Marčetić, G., Musa, A., Đulabić, V., \& Lalić Novak, G. (2014). Upravna znanost. Zagreb: Pravni Fakultet Sveučilišta u Zagrebu.

Lackowska, M. (2014). Polish cities face the Europeanization of post-socialist cities as a type of outward political rescaling. Croatian and Comparative Public Administration, 14(1), 31-58.

Lazin, F. (2014). Local government reforms in Eastern Europe after the collapse of the Soviet Union: Some observations. Croatian and Comparative Public Administration, 14(1), 59-84.

Maksimovska, A., \& Stojkov, A. (2016). Social responsiveness and service performance of local government: The case of Macedonia. Croatian and Comparative Public Administration, 16(2), 219-239.

Manojlović Toman, R., Vukojičić Tomić, T., \& Koprić, I. (2019). Unsuccessful Europeanization of Croatian sub-municipal government: Insufficient attractiveness or bad institutional design. Godišnjak Akademije Pravnih Znanosti Hrvatske, 10(1), 186-210.

Marčetić, G., \& Lopižić, I. (2017). Utjecaj procesa decentralizacije na jačanje personalnih kapaciteta hrvatske lokalne i područne (regionalne) samouprave. Croatian and Comparative Public Administration, 17(3), 407-435.

Musa, A., Bebić, D., \& Đurman, P. (2015). Transparency and openness in local governance: A case of Croatian cities. Croatian and Comparative Public Administration, 15(2), 415-450.

Pevcin, P., \& Rakar, I. (2015). Local public services in Slovenia-legal, organizational, economic and financial aspects. Croatian and Comparative Public Administration, 15(3), 697-714.

Pusić, E. (2002). Upravljanje u suvremenojdržavi. Zagreb: Društvenoveleučilište u Zagrebu.

Republika Hrvatska Ministarstvo Uprave. (n.d.). Popis županija, gradova i općina (In Croatia exist 428 municipalities and 127 cities). $\quad$ Retrieved from https://uprava.gov.hr/o-ministarstvu/ustrojstvo/uprava-za-politicki-sustav-i-organizaciju-uprave/lokalna-i-podrucna-regionaln a-samouprava/popis-zupanija-gradova-i-opcina/846

Rosenbaum, A. (2003). Decentralization in comparative perspective: Some lessons for building effective and democratic local governance. In A. Roeanbaum and L. Gajdošova (Eds.), State modernization and decentralization—implications for education and training in public administration: Selected Central European and global perspectives (pp. 33-41). UNDESA, IASIA \& NISPAcee.

Saito, F. (2008). Decentralization and local governance. In F. Saito (Ed.), Foundations for local governance (pp. 1-24). Heidelberg: Physica Verlag. 
Sarvan, D. (2016). Upravljanje vodnim uslugama kao faktor teritorijalne integracije integracije lokalnih jedinica. Hrvatska $i$ Komparativna Javna Uprava, 16(2), 295-319.

Swianiewicz, P. (2014). The unfinished story of the ugly duckling: Polish regions under the realm of Europeanization. Croatian and Comparative Public Administration, 14(2), 355-380.

Vezbergaite, I. (2016). Decentralization policies, subnational autonomy and federal executive power: A comparison of Brazil and Mexico. Croatian and Comparative Public Administration, 16(1), 55-76. 